\title{
Business lobbying under salience - financial industry mobilization against the European financial transaction tax
}

\author{
Lisa Kastner \\ Max Planck Sciences Po Center on Coping with Instability in Market Societies, Sciences Po, \\ Paris Cedex, France
}

\begin{abstract}
This article examines interest group conflicts surrounding the financial transaction tax (FTT) debate in the European Union (EU). Specifically, it focuses on the advocacy efforts of EU-based financial industry groups at different stages of the policy debate. The article provides a detailed description of changes to the post-crisis regulatory environment and points to public salience as important factor that can constrain business power. Much in line with the existing literature, industry groups did not fare very well under conditions of high salience and public pressure during the agendasetting stage. However, this article also shows that in order to get back on its feet, the financial sector lobby had to employ a combination of quiet and noisy politics during later stages of the policy process. As soon as the contextual conditions provided by the financial crisis started to fade away, industry groups were able to bounce back by using a framing strategy that linked their arguments against an FTT to broader societal goals, by disseminating scientific evidence and by building coalitions with business groups outside of finance in order to water-down the proposed directive.
\end{abstract}

KEYWORDS EU financial regulation; financial crisis; financial transactions tax; interest groups; lobbying

\section{Introduction}

A large public coalition between civil society organizations, trade unions and some member states' governments demanded the introduction of a financial transaction tax (FTT) in order to make the financial sector pay its fair share for economic recovery after the 2008 financial crisis. So, in January 2013, 11 eurozone countries came up with an ambitious reform proposal that included a broad-based tax with very few exemptions. Massive industry lobbying has since successfully watered down the Commission proposal, which now resembles a narrow tax with many exemptions for various financial instruments. Despite continued statements of support for such a tax by heads of state and governmentm as well as finance ministers of participating 
member states renewing their political commitment to an FT, a start date in 2017 has become increasingly unlikely (KPMG 2016).

From a theoretical point of view, the lobby success of the financial industry is somewhat surprising. Culpepper's (2011) distinction among 'quiet' and 'noisy' politics suggests that, in particular, under conditions of noisy politics when the public pays attention, highly organized business groups oftentimes lose, whereas under conditions of quiet politics, when interest group politics take place behind closed doors, business groups prevail. Applying his theory to post-crisis politics, Culpepper (2011: 197) predicted 'a weakened bargaining position' for organized interests in a 'radically changed political environment' and 'under intense public scrutiny'. Accordingly, scholars found that the financial crisis and the public outrage it caused was a catalyst in changing interest group dynamics that at least temporarily weakened the financial sector (Baker 2010; Clapp and Helleiner 2012; Kastner 2014; Orban 2016; Steinlin and Trampusch 2012; Woll 2013; Young 2013). How, then, can we explain the lobbying success of financial industry groups on a highly salient issue such as the FTT?

This article will show that in order to get back on its feet, industry groups had to employ a combination of quiet and noisy business politics. By examining a case where chances for industry groups to succeed in their lobbying efforts were low (or least likely), as the FTT with its important re-distributional consequences and high popular support, this article will shed light on a question that has so far largely been ignored by the literature, namely: how industry lobbyists were able to use noisy politics in response to the financial crisis to their advantage. ${ }^{1}$ This article also provides an important contribution to the existing international political economy (IPE) literature, which has so far largely ignored the effects of the crisis on industry groups' lobbying capacity (Pagliari and Young 2013).

Process-tracing will be used in order to open the black box of preference attainment of interest groups. The analysis here closely follows methodological guidelines as suggested by Trampusch and Palier (2016) and Bennett and Checkel (2015). The empirical account draws on 65 semi-structured qualitative interviews with financial lobbyists, policy-makers and pro-reform advocates at EU level. For the selection of respondents, I followed a non-probability or purposive sampling approach (Mason 2002: 97). Hence, I interviewed senior-level élites that had detailed knowledge of the negotiations that took place, such as Commission officials, members of the European Parliament (MEPs), their policy advisors and affected lobbying groups. In order to measure interest group influence, interest groups' stated goals were compared (as a proxy for their true policy positions), triangulated with contextual information retrieved from public statements and submissions to public consultations, as well as the financial press and interviews with other actors involved in the debate (Mahoney 2007: 37). In the case study, regulatory change was systematically gauged against groups' advocacy goals. 
The article is structured as follows: the next section will briefly present the existing literature on industry influence and financial reforms. The subsequent section will outline the main characteristics of the proposed legislation as presented by the European Commission. After a brief description of the main competing camps in the policy debate, the article describes the changes to the regulatory environment and traces the lobbying efforts. The final section briefly summarizes the main findings and concludes.

\section{Theoretical approaches on financial reforms}

The sizable literature on interest groups reminds us that more resourceful actors have a much better chance of getting their voice heard than less well-resourced groups (Eising 2007: 356). This is even more so in the field of finance, where financial industry groups enjoy a structurally privileged position owing to the rise of finance capitalism (Streeck 2014). Hacker and Pierson (2010), for instance, argue that the organizational capacity of resourceful private interests to bring public policy in line with their interests accounts for overly industry-friendly regulatory politics in the United States (US), especially in the field of finance. However, in particular, in situations of high public salience, electoral considerations motivate politicians to listen less to business lobbies and more to the electorate (Culpepper 2011: 7). Similarly, Smith (2000) finds that a united business lobby might still lose because issues they jointly mobilize for are likely to be accompanied by increased public attention and by the counter-mobilization of public interest groups. This in turn amplifies electoral motives for decisions-makers to act in the public interest rather than pander to business preferences. Numerous studies, mostly focused on the American political system, testify to the recurring success of weak interests such as workers, consumer or public interest groups in spite of a conflict with more powerful business groups (Grossmann 2012; Smith 2000; Trumbull 2012; Vogel 1997). For the European Union, Dür et al. (2013) find that business groups are less influential than citizen groups during the decision-making stage, and in particular when policy issues are highly conflictual.

According to a recent strand of IPE research, the financial crisis had several important effects that at least temporarily weakened financial sector groups. First and foremost, the post-crisis financial regulatory environment was generally marked by increased issue salience and negative publicity for the financial sector. Quaglia (2010) observed that the circle of actors involved in financial regulatory policy-making has become less restricted. Scholars have generally emphasized populist pressures on policy-makers together with an increased awareness of the distributional consequences of regulatory failures owing to the crisis as driving force for more stringent regulation of the financial sector. Baker (2010: 656) observed that 'lobbying capacity and voice of 
bank lobbies are not what they were prior to the crisis. Their oppositional attitudes to regulation are softening, while regulators are emboldened.'

Heightened media attention raised by the financial crisis certainly increased the perception of undue industry influence. Clearly this loss of legitimacy of the financial sector also extended to big corporations deemed responsible for increasing inequality and economic insecurity as well as to governments, especially the EU, seen as too responsive to business pressure. Several studies stressed how this de-legitimization and increased public attention, in turn, led to a change in lobbying strategies, with industry groups refraining from vetoing policy proposals (Steinlin and Trampusch 2012; Young 2014), focusing their attention on different stages of the policy cycle or on the reversal of legislative decisions during the implementation stage (Young 2013). Woll (2013) argues that public outrage forced hedge fund industry lobbyists to adapt their strategies to governments' preferences.

Increased actor plurality, closely linked to and motivated by heightened issue salience, is a second factor that can account for decreasing industry influence. Quantitative analyses confirm that the mobilization of interest groups beyond financial groups in the regulatory debate following the crisis increased in the EU (Eising et al. 2013). The literature identifies two differing effects of increased actor plurality in financial reform debates: increased actor plurality might either allow industry groups to form coalitions with supportive non-industry groups to leverage their influence (Pagliari and Young 2013: 6); or it might have the opposite effect and reduce industry impact on regulatory politics when outsider groups successfully oppose industry preferences as a 'countervailing force' (Clapp and Helleiner 2012). Kastner (2014: 1), for example, argues that 'a polymorphous network of civil society organizations was able to gain momentum after the financial crisis and to influence the financial reform process'.

\section{Noisy business politics}

What all the above approaches have in common is their recognition that business power can be considerably curbed by conditions of high salience. A recent study on EU politics confirmed that business groups are less influential than citizen groups during the decision-making stage, and in particular when policy issues are highly conflictual (Dür et al. 2013: 33). Business interests can, however, also take advantage of highly salient and conflictual issues by expanding the battlefield to non-financial groups and by tying their arguments to a broader societal goal. Trumbull's (2012) argument that the ability of public interest groups to make policy appear legitimate accounts for their increased policy influence, especially when decision-makers are under public scrutiny, might also hold for industry groups. Similarly to citizen groups, industry groups can seek an outside lobbying campaign 
(whereby interest groups go beyond the legislative arena to lobby policymakers with media activity or the mobilization of grassroots) if they can successfully frame their demands by linking them to a broader public interest, such as keeping costs for consumers low or avoid damaging consequences for growth and corporate activity. This strategy of 'noisy business politics' has largely been overlooked in the business power literature (Keller 2016). This article will show how industry groups, in order to achieve their lobbying goals, employed a expertise-based framing strategy (Boräng and Naurin 2015) that linked their arguments against an FTT to the broader societal goal of economic growth.

\section{Regulatory change and group influence}

In September 2011, the Commission adopted a proposal for a Council directive on a common financial transaction tax to be implemented by 1 January 2014 across the then 27 member states in order to (1) to avoid a fragmentation of the internal market; (2) to ensure that the financial sector makes a fair contribution to recover the costs of the financial crisis, as well as to compensate for the 'under-taxation' of the financial sector owing to the value added tax (VAT) exemption; (3) to create disincentives for high-frequency trading (HFT); and (4) to enable the development of an FTT at global level. ${ }^{2}$ After an EU-wide introduction of an $\mathrm{FTT}$ as advocated by civil society groups and proposed by the Commission in its initial draft Directive in September 2011 was rejected by a majority of member states, including the United Kingdom (UK), Sweden and Luxembourg, a sub-group of 11 member states, spearheaded by France and Germany, decided in January 2013 to go ahead by introducing the FTT with enhanced co-operation that would only bind participating member states.

The Commission's comprehensive tax proposals following an 'all institutions, all markets, all instruments' approach (Schulmeister 2014) reflected important advocacy demands of pro-tax activists. Largely in line with activists' preferences, the proposed tax had a wide scope, including derivatives and pension funds. ${ }^{3}$ The tax would be levied on all financial transactions between financial institutions when at least one party to the transaction is located in the EU ('residence principle'). The tax proposal only included a few exemptions. To avoid individual citizens being negatively affected, the scope of the proposal excluded most consumer products, such as insurance contracts, mortgage lending and consumer credit. The proposal included a harmonized minimum of 0.1 per cent tax rate on shares and bonds and of 0.01 per cent on derivatives with revenues generated being shared between the EU and member states. The Commission estimated that the tax would raise around 57 billion euros every year (European Commission 2011). The Commission's second proposal for 11 countries mirrored the 
scope and objectives of its original FTT proposal. After lobbying of pro-tax activists for an anti-avoidance measure to prevent relocation of financial activities, the second Commission proposal complemented the residence principle with an 'issuance principle', whereby the tax would also be levied on financial institutions based in non-FTT jurisdictions when they trade in financial instruments that are issued in FTT jurisdictions (Grahl and Lysandrou 2013). Although pro-tax group demands for an even higher tax rate of 0.5 per cent, as well as for using revenues generated by the FTT to fund international development, were not reflected in the Commission proposal, the draft directives were very close to their advocacy goals (Wahl 2014).

After the initial victory of civil society groups, member states made little progress towards implementation. Negotiations on the FTT in the Commission's formal indirect taxation working party amongst the then EU27 as well as in informal meetings among the participating eleven member states were subject to massive lobbying by the financial services sector, which led to political gridlock and made the introduction of a broad-based FTT increasingly unlikely (Zimmermann 2014: 3). The German government was known to advocate a broad scope with few exemptions, while France and Italy advocated a smaller scope with an exemption for bonds, certain types of derivatives and repos. ${ }^{4}$ Having introduced their national transaction taxes in 2012 and 2013 respectively, France and Italy started to promote their versions of the tax at EU level.

In May 2014, then, 10 participating eurozone countries announced in a joint declaration the progressive introduction of a scaled back version of the original FTT proposal, that would 'first focus on the taxation of shares and some derivatives' (Financial Times 2014). Despite the official rhetoric of the participating member states in January 2015 'that the tax should be based on the principle of the widest possible base and low rates' (ECOFIN Council 2015), it now seems likely that the draft directive will be significantly less ambitious than the original Commission proposal and end up as a narrowbased FTT, similar to the 0.5 per cent UK stamp duty reserve tax on a limited number of transactions. The FTT has largely been emptied of its critical elements and is now likely to miss the mark of effectively tackling speculative trading (Schulmeister 2014; Zimmerman 2014). Council working group meetings throughout 2016 revealed significant differences among the 10 remaining participants (with Estonia having dropped out), the implementation of an FTT any time soon becomes even more questionable.

\section{Policy debate and actor plurality}

The political debate about an EU FTT was the subject of vocal and widespread campaigns by civil society activists. Pro-tax campaigns, such as the German 'Steuer gegen Armut', the Italian 'ZeroZeroCinque', the Spanish 'La Tasa 
Robin Hood' and the British 'Robin Hood Tax Campaign', promoting a small tax on the financial sector with its revenue attributed to public finances as well as global development assistance, mobilized to pressure policy-makers. In September 2009, several non-governmental organizations (NGOs), including World Economy, Ecology and Development (WEED), Stamp out Poverty, War on Want, Terre des Hommes and national groups of the Association for the Taxation of financial Transactions and Citizen's Action, sent a letter to the $\mathrm{G} 20$ urging heads of state and government to implement an international FTT 'to pay for the cost of the crisis in the north', 'to assist countries in the South to meet their development objectives', and to 'contribute to a reduction in speculation' (WEED 2009). By late 2009, early 2010, national campaigns in support of such a tax - dubbed a 'Robin Hood Tax', spanning not only currency transactions, but all sorts of financial instruments - were initiated by civil society groups, which were successful in gathering widespread political support in Germany, Italy and the UK. When prospects for the introduction of a global or EU-wide tax faded, groups mobilized for an FTT via enhanced co-operation, with revenues to be shared between international development, member states and the EU.

Conversely, and unsurprisingly, tremendous opposition to the FTT proposal came from the banking industry. From the very beginning, financial industry groups were unified in their opposition to an FTT. In the words of one lobbyist, 'all ... financial institutions agreed that we completely disagree. ${ }^{5}$ The day the Commission presented its proposal for the introduction of an EU-wide FTT in September 2011, the Financial Times headline read: 'Business attacks transaction tax plan.' According to the article, 'the proposal has been fiercely resisted by financial and business interests in Europe, pointing to a fierce political battle that lies ahead' (Financial Times 2011). After it had become clear that 11 member states were going ahead with its implementation and the likelihood of legislative success increased, industry groups intensified their lobbying against the legislative proposal to implement an $\mathrm{FTT}^{6}$ The proposal was subsequently substantially watered down during negotiations among member states, which started in February 2013. Nevertheless, the decision to introduce a policy directed at penalizing the financial sector speaks to the inability of industry groups to affect the policy agenda in line with their preferences. How can we explain the initial failure of industry groups to derail an EU FTT, despite their unified opposition?

\section{The post-crisis financial regulatory environment: high salience politics ${ }^{7}$}

In the post-crisis context, heads of states and governments, and notably French president Nicolas Sarkozy and German chancellor Angela Merkel, became interested in the FTT as a populist policy measure to appease 
public opinion. Increased public attention on financial reform also made the regulatory dialogue less conducive to private sector influence. By tracing the use of the phrase 'financial transaction tax' in newspapers, the increase in issues salience is clearly visible in Germany, France and the UK (Figure 1). ${ }^{8}$ With Merkel and Sarkozy at the forefront of the pro-tax camp, the FTT received most media attention in Germany and France. Media attention was considerably less in the UK, a country that opted out of the coalition of 11 countries proceeding with the introduction of an FTT. Media attention notably increased in 2011 with the FTT rising to the political agenda of the G20 meeting in Cannes in November that year. This was followed by a spike in attention in 2012, with the European Parliament (EP) voting in favour of an EU-wide FTT in May 2012 and 11 member states announcing their commitment to introduce an FTT via enhanced co-operation in June 2012, after failed Council negotiations for an EU-wide solution.

A public opinion poll carried out by the International Trade Union Confederation (ITUC) in June 2012 offers further evidence of the high salience of the FTT debate in Europe. Only 12 per cent of respondents in France indicated that they had never heard of a tax on financial transactions. About 30 per cent of respondents in Belgium, Greece and Germany and 37 per cent of

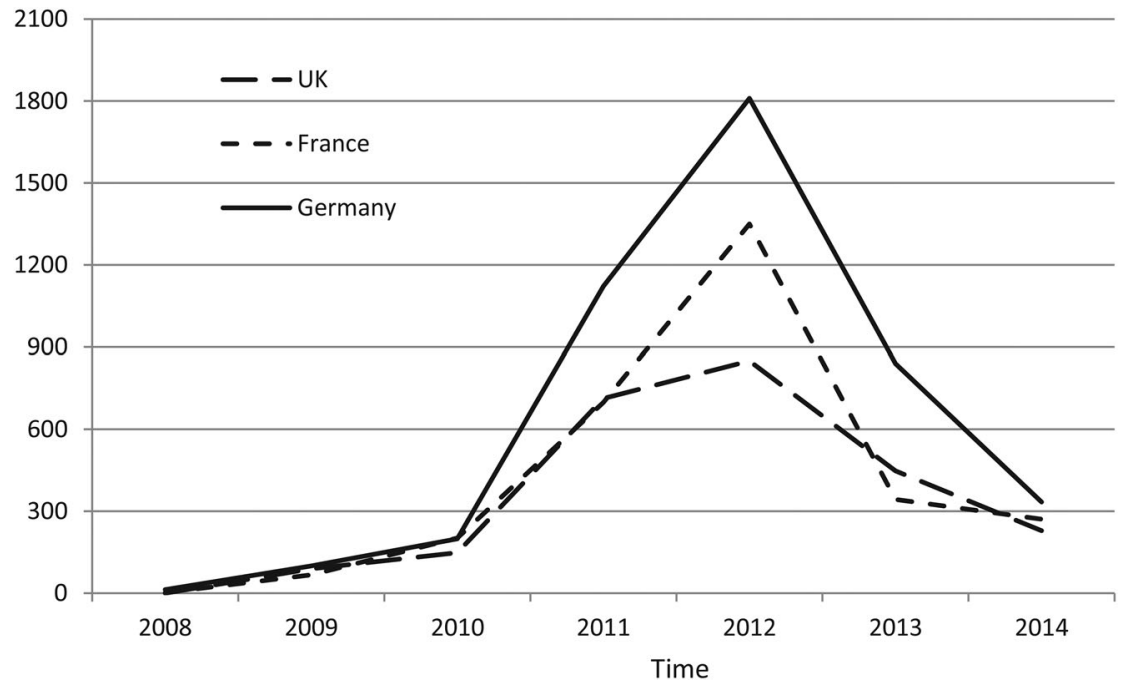

Figure 1. News coverage of the financial transaction tax. Source: Factiva.

Notes: Articles containing the search term "financial transaction tax" in British as well as US newspapers, "taxe sur les transactions financières" in the French language press and "Finanztransaktionssteuer" in the German language press, which refer to the relevant groupings of major publications proposed by Factiva (incl. The Financial Times, The Guardian, The Economist, CNN, The New York Times, Washington Post, Le Monde, Le Figaro, Agence France Presse, Frankfurter AllgemeineZeitung, SüddeutscheZeitung, Reuters, Spiegel Online).] 
respondents in the UK answered that they were not familiar with the idea (ITUC 2012). The vast majority of respondents in EU countries, therefore, were able to take a position on a rather opaque financial regulatory issue. In those early phases of the reform, financial industry groups, faced with adverse public opinion, were not successful in vetoing policy change. In the midst of the financial crisis, the dialogue among policy-makers and private sector groups was generally more adversarial than it had reportedly been during pre-crisis times. Expressing frustration about heightened public attention regarding the proposed $\mathrm{FTT}$, one industry lobbyist complained that it was 'difficult to have reasonable discussions if it becomes so much politicized'. The context for regulatory debate had noticeably changed for private sector groups and the mood swing in public opinion was clearly felt by industry lobbyists. Public outrage and de-legitimization of the industry were clearly felt by financial sector lobbyists, who perceived the tax as retribution for wrongdoings that led to the crisis. In the words of another interviewee: 'We are the ones to be punished.'

Increased public attention to the regulatory reform process was accompanied by divisions among policy-makers and the private sector. One important way in which the regulatory environment had changed was that policy-makers started to call industry groups' expertise into question. Public attention to financial debates had clearly weakened incentives for elected officials and politicians to openly heed demands coming from the financial sector. Wolfgang Schäuble, the German finance minister, for example, dismissed arguments from the opposing camp in November 2011:

The objections made by some who claim it would mean a substantial drop in employment and in the economy generally seem to rest on exaggerated and sharply challenged projections - and, more important, ignore the potential of such a tax to stabilize currency markets in a way to boost rather than damage the real economy. (The Telegraph 2011)

Statements of industry lobbyists in Brussels and London corroborate the story that their influence on the particular content of the proposed FTT prior to the publication of the Commission's first draft directive in September 2011 was rather limited. Before the financial crisis, industry groups were used to exchanging information with Commission officials, even before the publication of draft directives. After the financial crisis, as this industry representative complained, there had been no pre-legislative discussion among financial industry groups and Commission officials before the publication of the first FTT draft proposal in September 2011, apart from the Commission's public consultation between February and April 2011. In the perception of another industry representative, the Commission worked on the draft directive 'in complete isolation, not with the industry'. 
Financial sector participants were generally frustrated by the policy process and their inability to exert influence. One interviewee stated that his association was 'having a very tough time' when trying to engage in discussions with policy-makers about the FTT. Other commentaries from financial lobbyists confirm that it was 'difficult to have constructive discussions' with Commission officials and MEPs on the FTT. For industry lobbyists who reported having meetings with Algirdas Šemeta, the Commissioner for Taxation, as well as with Commission officials, discussions 'did not have a significant impact on the direction the Commission was traveling'. One disgruntled lobbyist reported that the Commission was generally 'dismissive' about industry concerns. This explains why industry representatives were irritated when they read the first Commission draft. Private sector lobbyists reported that they thought the Commission draft, once proposed, was 'that bad, you have to restart from scratch', that 'not a single measure [was] acceptable', that it did not 'accurately reflect how the financial markets work', and that the design of the tax was 'fundamentally flawed'.

Changes to the post-crisis financial regulatory environment also forced financial industry groups to adapt their lobbying strategies. From the beginning, financial industry groups saw their advocacy efforts directed at blocking or vetoing any legislative proposal regarding an FTT largely curtailed. Aware of the potentially negative consequences for their reputation, financial sector groups did, for example, employ only limited 'outside lobbying strategies'. In the context of huge bailout costs using public money, the financial services industry was facing serious reputational problems and saw itself deprived of the usual lobbying repertoire, as one financial lobbyist reported:

It is very difficult for the banking sector for example to go all out and oppose an FTT when they are beneficiaries of government bailouts ... The financial sector has found it very difficult to publicly articulate their opposition to the FTT without seeming to be just serving their own interest. ... the financial services sector has such a bad reputation.

Private sector groups refrained, for instance, from publishing position papers opposed to the FTT in order to avoid negative publicity.

\section{Changed contextual conditions: low-salience politics}

When legislative debate moved to the policy formulation stage, salience slowly faded away, with the FTT making the headlines less and less often. The decline in issue salience is clearly visible in Figure 1. An upsurge in interest in the issue in 2012, when 11 member states signalled their willingness to proceed with the introduction of an FTT by enhanced co-operation, was followed by a steady decline in press coverage throughout 2013, until reaching, by mid-2014, the lowest level of attention since the start of reform debates in 2009. 
The drop in public attention parallels the move of legislative debates from the top of policy agendas to working group meetings. Shortly after the Commission had presented a second draft directive for enhanced co-operation in February 2013, negotiations moved to the Commission's indirect taxation working party. These working party meetings (among all 27 member states) were characterized by a noticeable 'quietening' of regulatory debates with much less public scrutiny. In addition, negotiations started to take place in unofficial meetings among participating member states prior to the formal working party meetings. Discussions about proposed legislation were thereby narrowed down from a broader public debate to a limited circle of participants and non-official working party papers. It is also indicative of fading salience of the policy issue that in June 2013 the FTT was not included on the agenda of the Economic and Financial Affairs Council (ECOFIN), nor the EU's Summit.

When debates moved from high issue salience to lower issue salience and from broad democratic debate toward special interest bargaining, new possibilities opened up for exemption, delay and modification beneficial to industry interests. It is therefore little surprising that industry groups started to step up their lobbying efforts directed at member states negotiations in the Council. According to one industry representative:

We haven't even tried to contact the Commission on this. Parliament is an area where we might be lobbying more but we haven't done anything. We believe that it is really the governments that are going to decide and primarily the French and German governments. ${ }^{9}$

Reform discussions in informal meetings resulted in a perceived lack of transparency in the decision-making process. Non-participating member states criticized the negotiations as 'closed process', 'a political deal negotiated largely in secret' (Financial Times 2014). In June 2012, Green MEP and supporter of the FTT Lamberts expressed his frustration about the policy process:

[I]t has become clear that the proposal for the tax, presented by the European Commission in February, is being torn apart by governments with close relationships to the financial lobbies. Since they [governments] are acting behind closed doors, in ambassadors'meetings, in central bankers' gatherings, beyond public pressure and democratic accountability, they feel free to destroy the Commission's ambitious proposals. (Lamberts 2013)

\section{The success of noisy business politics}

One effect of increased salience and actor plurality was that opponents of an FTT were reticent in making a public case outright opposing an FTT in the early phases of the policy process when the memory of the financial crisis was still fresh. Yet, despite greatly improved chances for an FTT 
after the second Commission proposal in February 2013, and under conditions of more quiet politics, financial industry groups changed their lobbying strategy. It was then that industry groups started to actively push back, launching 'a concerted and broad attack' against the FTT from March to June 2013 (Persaud 2013). Industry representatives went public, warning about the potentially harmful economic implications of the proposed reform choosing frames that focused on public interests and societal costs. First, industry groups engaged in noisy politics by distributing a clearly understandable message to the broader public about the harmful effects of the reform strongly backed up by scientific evidence. In early 2013, banks (Goldman Sachs, Deutsche Bank, Citigroup, Morgan Stanley) and their lobbying associations (the International Banking Federation and the European Fund and Asset Management Association) published a range of research reports presenting empirical evidence against an FT. In its research report 'Financial Transaction Tax: how severe?', Goldman Sachs claimed the proposed FTT would lead to a massive tax burden for the banking sector, amounting to $€ 170$ billion. The report further claimed that 'the burden of the FTT would fall on retail investors' (Goldman Sachs 2013). Industry groups were also careful to highlight the undesirable societal costs of the proposed tax reform. When arguing for exemptions from the scope of the tax, industry groups typically argued that the inclusion of the respective financial instruments within the scope of the tax would lead to liquidity problems with detrimental consequences for the wider economy. In a research report from March 2013, Deutsche Bank stated its opposition to the proposed tax, presenting evidence that the FTT would raise the cost of capital 'for households, firms and even states' and therefore 'hurt the real economy' (Deutsche Bank Research 2013). Several more studies, press releases and commentaries in major newspapers brought arguments and scientific evidence forward against the FTT (Bloomberg Business 2013; Financial Times 2013a, 2013b).

In an effort to leverage their political influence, financial industry groups also tried to tie their interests to those of other private sector groups indirectly affected by the introduction of an FTT. With their expertise and credibility discredited by the crisis, industry groups had to choose their coalition partners wisely in order to be able to make convincing counter-arguments to the proposed policy reforms. As such, financial sector groups in the eurozone deliberately chose not to organize joint campaigns with US- and UK-based financial firms because there was a perception that arguments coming from the latter were rather counterproductive in efforts to convince EU policymakers to oppose an FTT. As one industry representative reported: 'There is a risk that lobbying ... is not very helpful because it is all a bit the Anglo-Saxon conspiracy to preserve its financial markets ... We share information but we are not involved in any joint initiatives. ${ }^{\prime 10}$ Although they refrained from joint 
campaigns with US- and UK-based firms, financial groups took advantage of the counter-mobilization of non-financial groups within the business community. Policy-makers were not eager to publicly support the finance industry's arguments opposing regulatory reform, but they equally shied away from publicly supporting regulatory reforms that could be seen to have negatively affected corporate activity and economic growth. A significant number of actively mobilized against the introduction of an FTT. In May 2013, German multinational companies including Bayer and Siemens voiced their opposition to the proposed $\mathrm{FTT}$, highlighting its damaging effects for companies and the export-oriented German economy (Financial Times 2013c). One financial industry representative explained the lobbying strategy as follows:

The better way for the financial sector to address this topic is to get other parties on board. When Deutsche Bank complains, people say it must be good but if Siemens says it is detrimental to clients, you make a strong argument. ${ }^{11}$

Although non-financial business actors were not the actual target of the regulation, they feared that one of the downstream costs of the tax would be to raise the cost of corporate debt. Rather than stressing the potential effects of the tax on financial markets, business associations emphasized the damaging consequences for growth and corporate activity. Accordingly, the American Chamber of Commerce argued in letters sent to participating EU member states that the tax 'will have serious implications not just for the financial institutions but for the "real economy" - on businesses in every sector who legitimately use financial instruments in the normal course of their business'. This argument was made in a non-public paper on the FTT from April 2013, provided by a London-based bank lobbyist. Citing these arguments financial sector groups actively lobbied against the FTT - a campaign that Der Spiegel, a German weekly news magazine, described as a 'revolt' aimed at delaying its implementation (Hesse and Pauly 2012). Next to business groups, financial industry groups found another important ally in the community of central bankers. Financial sector groups repeatedly criticized the proposed FTT during advisory groups meetings with European Central Bank (ECB) staff in spring 2013 (Corporate Europe Observatory 2013). In April and May 2013, then, the heads of the German, French and British central banks publicly expressed their reservations towards an FTT (Financial Times 2013d; The Telegraph 2013). After reports and lobbying by the financial industry had shed considerable doubt on the desirability of the tax, political support clearly faded. In May 2014, German Finance Minister Schäuble declared that the options, interests and situation of the various participants were so divergent that states should start by introducing a limited taxation of shares and some derivatives (Wall Street Journal 2013). 


\section{Conclusions}

In the post-crisis context, heads of states and governments became interested in the FTT as a populist policy measure to appease public opinion. In those early phases of the reform, advocacy efforts of financial sector groups, faced with adverse public opinion aimed at blocking regulatory change, were largely frustrated. Industry groups saw themselves deprived of their full lobbying repertoire and largely refrained from outside strategies. This early phase of the reform debate clearly evokes the extent to which regulatory capture by concentrated industry interests is constrained, both by heightened salience and interest group plurality. Contextual conditions changed dramatically when the regulatory debate moved to the actual policy formulation stage. Under much less public scrutiny, negotiations among the 11 participating member states were much more conducive to private sector lobbying than the previous debate. Working group meetings received, for example, considerable less press coverage than previous FTT debates. This 'quietening' of the policy debate combined with a framing strategy and a more encompassing and diverse coalition of stakeholders was key to the industry's lobbying success. Industry groups started to exercise instrumental power during the negotiation phase among Council working groups, by presenting scientific evidence against a transaction tax, by pointing out potential societal costs and by forming strategic lobby alliances with central business groups such as Bayer and Siemens. The mobilization of groups, not directly affected by the proposed regulatory reforms, positively affected the financial industry's advocacy efforts. Owing to the successful framing of the tax as harmful to economic growth, the distribution of scientific evidence to back up the argument and the active opposition of a coalition among industry and business groups, the proposed tax eventually resulted in a diluted compromise. Latest reform proposals indicate that the FTT is likely to miss the mark of effectively raising revenue and tackling speculative trading. Far from a long-term shift in the balance of power, developments in financial regulatory reforms after the crisis seem to be more of a temporary setback for industry groups, following the usual boom and bust cycle.

This analysis followed a deviant case logic, since the lobbying success of business groups against an FTT is puzzling in light of the literature, which led us to expect that business groups lose if subjected to public scrutiny. The case thus provides a unique opportunity to fine-tune existing theory. First and foremost, it provides empirical support to the noisy business politics hypothesis that postulates that the business community may successfully employ framing when faced with new regulations. A framing strategy that linked industry arguments against regulation to the well-being of the broader economy was the winning strategy when aimed at national governments concerned with the legitimacy of their public policy decisions. Framing 
strategies aimed at a broader public are particularly useful for business groups when issue salience declines. In the context of low salience, business groups can benefit from using the media to convince policy-makers of their view of the policy issue at hand (Boräng and Naurin 2015). Industry groups' use of outside lobbying strategies was much more constrained in the context of high salience. The study therefore also shows that within case variance in salience is important in understanding lobbying success.

The caveat here is that it is not easy to quantify and conclusively ascertain the precise influence of group advocacy in the course of the financial reforms. Critics may argue that reform ambitions shrank because governments 'learned' that the proposal of a uniform tax on very different types of transactions would potentially cause serious malfunctions, and that it would be more effective and technically simpler to tax net revenues of the financial sector (see, for example, Grahl and Lysandrou 2003, 2013). However, although alternative policy solutions to the FTT such as the financial activities tax (FAT) were well known, not one of the main political players seriously considered replacing the FTT proposal by an FAT proposal.

Second, the reform proposal might also have been diluted because the Commission feared that even more member states would opt out if the proposal was not watered down. It might indeed be overstretching the evidence to conclude that the lobbying efforts of the financial industry alone were decisive. However, noisy business politics most likely made it easier for political actors to use the same frame employed by industry groups to support a diluted FTT.

Third, one may argue that it has not been the instrumental power but the structural power of financial capital that eroded the ambition of the initial FTT proposal. While instrumental power is based on the lobbying capacity of business groups, structural power refers to the structural dependence of capitalist democracies on firm investments, which provides the latter with political leverage even if financial sector groups do not actively engage in advocacy (Culpepper 2015; Culpepper and Reinke 2014; Woll 2014). Research evolving around the concept of 'financialization' has identified the growing centrality of the financial industry as a major trend in socioeconomic developments (Krippner 2011). Owing to the centrality of finance capital in modern market societies, any attempt to re-regulate financial industry activities must therefore be understood as a direct challenge to the vested interests of finance capitalism. More importantly, re-regulations in the field of finance are likely to have repercussions not only for the financial industry but for the wider business community alike. Business groups are therefore more likely to align with financial sector groups' advocacy efforts (Pagliari and Young 2015). It is therefore likely that a combination of instrumental and structural power of financial industry groups may explain why lobbying demands of EU-based industry groups were eventually successful in diluting the proposed reform. 


\section{Notes}

1. A notable exception is the article by Keller (2016).

2. Proposal for a Council Directive on a common system of financial transaction tax and amending Directive 2008/7/EC, Brussels, 28 September 2011.

3. Interview with an NGO representative, 13 September 2013.

4. Internal and non-official paper provided by financial lobbyist, June 2013.

5. Interview with industry representative, Brussels, 22 May 2013.

6. Interview with Commission official, Brussels, 12 May 2013.

7. This section is based on interviews with industry lobbyists conducted in Brussels and London in May and June 2013.

8. I have selected the three key member states for illustration purposes and because their stance on the negotiations can be considered particularly relevant to the reform outcome.

9. Interview with industry representative, London, 20 June 2013.

10. Ibid.

11. Interview with financial industry lobbyist, 16 May 2013.

\section{Disclosure statement}

No potential conflict of interest was reported by the author.

\section{Notes on contributor}

Lisa Kastner is policy advisor at the Foundation for European Progressive Studies (FEPS). She is also associate fellow at the Max Planck Sciences Po Center (MaxPo) on Coping with Instability in Market Societies and the Centre d'études européennes, Sciences Po Paris. This article was mainly written during a post-doc at the MaxPo Center and at FEPS.

\section{References}

Baker, A. (2010) ‘Restraining regulatory capture? Anglo-America, crisis politics and trajectories of change in global financial governance', International Affairs 86(3): 647-63.

Bennett, A. and Checkel, J.T. (2015) Process Tracing: From Metaphor to Analytic Tool, Cambridge: Cambridge University Press.

Bloomberg Business (2013) 'EU aides say transaction tax design hurts sovereign debt', 22 May, available at www.bloomberg.com/news/articles/2013-05-21/eu-aides-saytransaction-tax-design-hurts-sovereign-debt (accessed 19 September 2016).

Boräng, F. and Naurin, D. (2015) “Try to see it my way!' Frame congruence between lobbyists and European Commission officials', Journal of European Public Policy 22(4): 499-515.

Clapp, J. and Helleiner E. (2012) 'Troubled futures? The global food crisis and the politics of agricultural derivatives regulation', Review of International Political Economy 19(2): 181-207.

Corporate European Observatory (2013) 'Robbing the Robin Hood Tax: the European Central Bank weighs in', 17 July, http://corporateeurope.org/financial-lobby/2013/ 07/robbing-robin-hood-tax-european-central-bank-weighs (accessed 14 September 2015). 
Culpepper, P.D. (2015) 'Structural power and political science in the post-crisis era', Business and Politics 17(3): 391-409.

Culpepper, P.D. (2011) Quiet Politics and Business Power: Corporate Control in Europe and Japan, Cambridge: Cambridge University Press.

Culpepper, P.D. and Reinke, R. (2014) 'Structural power and bank bailouts in the United Kingdom and the United States', Politics and Society 42(4): 427-54.

Deutsche Bank Research (2013) 'Financial transaction tax. Counterproductive', available at www.goldmansachs.com/s/GMeT_othermailings_attachments/6350048491761 7250089163.PDF (accessed 14 September 2015).

Dür, A., Bernhagen, P. and Marshall, D.J. (2013) 'Interest group success in the European union: when (and why) does business lose?', Paper presented at the annual conference of the European Political Science Association, Barcelona, 20-22 June, available at papers.ssrn.com/abstract=2225099 (accessed September 2016).

ECOFIN Council (2015) 'Joint statement by ministers of member states participating in enhanced cooperation in the area of financial transaction tax', 27 January.

Eising, R. (2007) 'Institutional context, organizational resources and strategic choices', European Union Politics 8(3): 329-62.

Eising, R., Rasch, D. and Rozbicka, P. (2013) 'EU financial market regulation and stakeholder consultations', Paper presented at the Institute for European Studies, Université Libre de Bruxelles, 18-19 April, available at www.intereuro.eu/public/ downloads/publications/Eising_Rasch_Rozbicka_2013_EU_financial_market_ regulation_and_stakeholder_consultations.pdf?phpMyAdmin= bc921356f086070c90aa893e9eb2bead (accessed September 2016).

European Commission (2011) 'Press release - financial transaction tax: making the Financial sector pay its fair share', available at europa.eu/rapid/press-release_IP11-1085_en.htm?locale=en (accessed September 2016).

Financial Times (2011) 'Business attacks transaction tax plan', 28 September, available at http://www.ft.com/intl/cms/s/0/f9d2188a-e9ec-11e0-a149-00144feab49a. html\#axzz2NnskvMIJ (accessed September 2016).

Financial Times (2013a) 'Funds hit at planned European transactions tax', 30 April, available at www.ft.com/intl/cms/s/0/411cb28c-b1aa-11e2-b324-00144feabdc0.html \#axzz2RpNXyGSM (accessed September 2016).

Financial Times (2013b) 'Banks call on BoE to oppose financial transaction tax', 5 May, available at www.ft.com/intl/cms/s/0/948b16a6-b589-11e2-850d-00144feabdc0. html\#axzz2Sa5SdDEN (accessed September 2016).

Financial Times (2013c) 'German companies weigh in against tobin tax', 8 May, available at www.ft.com/intl/cms/s/0/5cb60a60-b7d2-11e2-bd62-00144feabdc0.html\#axzz 2Sa5SdDEN (accessed September 2016).

Financial Times (2013d) 'ECB offers to help Rethink Robin Hood tax', 26 May, available at www.ft.com/content/c3121802-c480-11e2-9ac0-00144feab7de September 2016).

Financial Times (2014) 'Eurozone divided over financial transaction tax deal', 6 May, available at www.ft.com/intl/cms/s/0/d8a5d630-d529-11e3-9187-00144feabdc0. html\#axzz3aTjJISHn (accessed September 2016).

Goldman Sachs (2013) 'Financial transaction tax: how severe?', Goldman Sachs Global Investment Research, available at www.steuer-gegen-armut.org/fileadmin/Dateien/ Kapagnen-Seite/Unterstuetzung_Ausland/EU/2013/201 3.05._GS_on_Fin_I_Trans action_tax_FT___Bottom_Up_Analysis_Europe.pdf (accessed September 2016).

Grahl, J. and Lysandrou, P. (2003) 'Sand in the wheels or spanner in the works? The Tobin tax and global finance', Cambridge Journal of Economics 27: 597-621. 
Grahl, J. and Lysandrou, P. (2013) The European commission's proposal for a financial transactions tax: a critical assessment, JCMS: Journal of Common Market Studies 52(2): 234-49.

Grossmann, M. (2012) 'Interest group influence on US policy change: an assessment based on policy history', Interest Groups \& Advocacy 1(2): 171-92.

Hacker, J.S. and Pierson, P. (2010) 'Winner-take-all politics: Public policy, political organization, and the precipitous rise of top incomes in the United States', Politics \& Society 38(2): 152-204.

Hesse, M. and Pauly, C. 2012. 'Financial Lobby in Revolt: how much longer can transaction tax be delayed?' Spiegel Online International, 20 March, available at www. spiegel.de/international/europe/financial-industry-lobbyists-delay-financialtransaction-tax-a-822186.html (accessed November 2015).

ITUC (2012) 'ITUC global poll 2012 - how banks can contribute to society: very strong popular support for financial transactions tax', available at www.ituc-csi.org/itucglobal-poll-2012-how-banks (accessed September 2016).

Keller, E. (2016) 'Noisy business politics: lobbying strategies and business influence after the financial crisis', Journal of European Public Policy, DOI: 10.1080/ 13501763.2016.1249013.

Kastner, L. (2014) “Much ado about nothing?' Transnational civil society, consumer protection and financial regulatory reform', Review of International Political Economy 21 (6): 1313-345.

Krippner, G. (2011) Capitalizing on Crisis the Political Origins of the Rise of Finance, Cambridge, MA: Harvard University Press.

KPMG (2016) 'European financial transaction tax', 23 November, available at home.kpmg.com/uk/en/home/services/tax/corporate-tax/european-financial-transactiontax.html (accessed 19 November 2016).

Lamberts, P (2013) 'The Robin Hood tax is under attack', The Guardian, 7 June, available at www.theguardian.com/commentisfree/2013/jun/07/robin-hood-tax-under-attack (accessed November 2015).

Mahoney, C. (2007) 'Lobbying success in the United States and the European union', Journal of Public Policy 27(1): 35-56.

Mason, J. (2002) Qualitative Researching, 2nd edition. London; Thousand Oaks, CA: SAGE Publications Ltd.

Orban, A. (2016) 'Mobilizing moral boundaries: the politics of derivatives reform in the US', New Political Economy 21(6): 555-73.

Pagliari, S. and Young, K. (2013) 'The wall Street-main street nexus in financial regulation: business coalitions inside and outside the financial sector in the regulation of OTC derivatives', in M. Moschella and E. Tsingou (eds.), Great Expectations, Slow Transformations: Incremental Change in Financial Governance, Colchester: ECPR Press, pp. 125-48.

Pagliari, S. and Young, K.L. (2015) 'Capital united? Business unity in regulatory politics and the special place of finance', Regulation and Governance. doi:10.1111/ rego.12098.

Persaud, A. (2013) 'Europe should embrace a financial transaction tax', Financial Times, 28 May, available at www.ft.com/intl/cms/s/0/ba8e4232-c79b-11e2-95200144feab7de.html?siteedition=int|\#axzz2UYOZaMQz (accessed September 2016).

Quaglia, L. (2010) Governing Financial Services in the European Union: Banking, Securities and Posttrading, London: Routledge. 
Schulmeister, S. (2014) 'The struggle over the financial transactions tax-a politico-economic farce', WIFO Working Paper, June 25, available at http://www.wifo.ac.at/ publikationen?detail-view=yes\&publikation_id=47272 (accessed September 2016).

Smith, M.A. (2000) American Business and Political Power, Chicago: The University of Chicago Press.

Steinlin, S. and Trampusch, C. (2012) 'Institutional shrinkage: the deviant case of Swiss banking secrecy', Regulation \& Governance 6(2): 242-59.

Streeck, W. (2014) Buying Time: The Delayed Crisis of Democratic Capitalism, Brooklyn: Verso.

The Telegraph (2011) 'Archbishop of canterbury Rowan Williams calls for new tax on bankers', November 1, available at www.telegraph.co.uk/news/religion/8863794/ Archbishop-of-Canterbury-Rowan-Williams-calls-for-new-tax-on-bankers.html (accessed September 2016).

The Telegraph (2013) 'France' central banks head warns FTT could 'destroy' jobs', May 28, available at http://www.telegraph.co.uk/finance/newsbysector/banksandfinance/ 10084008/Frances-central-bank-head-warns-FTT-could-destroy-jobs.html.

Trampusch, C. and Palier, B. (2016) 'Between X and Y: how process tracing contributes to opening the black box of causality', New Political Economy 21(5): 437-54.

Trumbull, G. (2012) Strength in Numbers: The Political Power of Weak Interests, Cambridge, MA: Harvard University Press.

Vogel, D. (1997) Trading up: Consumer and Environmental Regulation in a Global Economy, Cambridge, MA: Harvard University Press.

Wahl, P. (2014) 'The European civil society campaign on the financial transaction tax', Working Paper, No. 20, Global Labour University project 'Combating Inequality', Geneva, February, available at www.global-labour-university.org/fileadmin/GLU_ Working_Papers/GLU_WP_No.20.pdf (accessed September 2016).

Wall Street Journal (2013) 'EU tax should start with derivatives, shares says German finance minister', 5 May, available at www.wsj.com/news/articles/SB10001 424052702303417104579543533755401604?mod=dist_smartbrief (accessed September 2016).

WEED (2009) 'International financial transaction tax on the Pittsburgh agenda', available at www.globaleverantwortung.at/images/doku/g20_pittsburgh_financi altransactiontax_sept09.pdf (accessed September 2016).

Woll, C. (2013) 'Lobbying under pressure: the effect of salience on European union hedge fund Regulation', JCMS: Journal of Common Market Studies 51(3): 555-72.

Woll, C. (2014) The Power of Inaction. Bank Bailouts in Comparison, Ithaca: Cornell University Press.

Young, K.L. (2013) 'Financial industry groups' adaptation to the post-crisis regulatory environment: changing approaches to the policy cycle', Regulation \& Governance 7(4): 460-80.

Young, K.L. (2014) 'Losing abroad but winning at home: European financial industry groups in global financial governance since the crisis', Journal of European Public Policy 21(3): 367-88.

Zimmermann, H. (2014) 'EU-11 Als Globale Avantgarde?: Die Verhandlungen Um Eine Finanztransaktionssteuer', available at edoc.vifapol.de/opus/volltexte/2014/5394/ pdf /GGS_2014_02_de.pdf (accessed Septmber 2016). 